\title{
PENILAIAN KOMPETENSI MENGAJI CALON GURU MELALUI TEKNIK ANALISIS MATRIK USG DI SDIT BAITUL IZZAH NGANJUK
}

\author{
Bagus Rachmad Saputra \\ Manajemen Pendidikan-Universitas Negeri Malang \\ E-mail: bagusrachmad47@gmail.com \\ Sultoni \\ Administrasi Pendidikan-Universitas Negeri Malang \\ E-mail: sultoni.fip@um.ac.id
}

\begin{abstract}
This study aims to help schools namely SDIT Baitul Izzah (Baiz) Nganjuk Regency to solve human resource problems by using USG matrix analysis techniques. This research uses a qualitative research approach by conducting field studies directly observing the field, interviewing the principal as a resource person, and conducting documentation studies relating to the recruitment process of new teachers. The results of this study found: (1) the problem of human resources in schools about the prospective teachers recruited lacking the ability to study, (2) USG matrix analysis techniques used to analyze human resource problems in schools, (3) suggestions and solutions to schools to solve the problem of human resources about prospective teachers recruited lacking the competence to read through the results of problem analysis using USG matrix techniques.
\end{abstract}

Keywords: USG Matrix, teacher, competence

\begin{abstract}
Abstrak: : Penelitian ini bertujuan untuk membantu sekolah yakni SDIT Baitul Izzah (Baiz) Kabupaten Nganjuk untuk menyelesaikan masalah sumber daya manusia dengan menggunakan teknik analisis masalah matrik USG. Penelitian ini menggunakan pendekatan penelitian kualitatif dengan melakukan studi lapangan pengamatan langsung ke lapangan, wawancara dengan kepala sekolah sebagai narasumber, dan melakukan studi dokumentasi yang berkaitan dengan proses rekrutmen guru baru. Hasil dari penelitian ini menemukan: (1) masalah sumber daya manusia di sekolah tentang calon guru yang direkrut kurang memiliki kompetensi mengaji, (2) Teknik analisis masalah matrik USG yang digunakan untuk menganalisis masalah sumber daya manusia di sekolah, (3) saran dan solusi kepada sekolah untuk menyelesaikan masalah sumber daya manusia tentang calon guru yang direkrut kurang memiliki kompetensi mengaji melalui hasil analisis masalah menggunakan teknik matrik USG.
\end{abstract}

Kata Kunci: Matrik USG, guru, kompetensi 
Lembaga pendidikan yakni sekolah dalam merekrut calon tenaga pendidik atau guru pasti mempertimbangkan beberapa aspek tentang kompetensi yang harus dimiliki oleh calon guru yang melamar ke sekolah. Hal ini berkaitan dengan profesionalitas guru dalam mengajar di sekolah, dengan kompetensi yang dimiliki oleh guru tentu akan berdampak pada pelaksanaan program pembelajaran di sekolah yang kemudian berdampak pada kualitas pembelajaran sekolah sebagai daya tarik masyarakat terhadap sekolah. Berdasarkan UndangUndang Nomor 14 Tahun 2005 Tentang Guru dan Dosen, kompetensi guru yang harus dimiliki guru adalah: (1) kompetensi pedagogik, (2) kompetensi kepribadian, (3) kompetensi sosial, dan (4) kompetensi profesional. Artinya keempat kompetensi tersebut merupakan kompetensi inti yang harus dimiliki oleh guru maupun calon guru yang sedang melamar ke sebuah sekolah.

Sebagai sekolah berbasis Agama Islam yang memadukan antara pembelajaran formal umum dengan nilai-nilai Agama. Selain empat kompetensi diatas yang wajib dimiliki guru yang ada di SDIT Baiz, ada satu kompetensi tambahan yang harus dikuasai dengan baik oleh guru dan calon guru yang melamar di SDIT Baiz. Kompetensi tersebut yakni kompetensi mengaji, yang bukan sekedar mampu membaca kitab suci Al Qur'an namun juga hafal tajwid dan hukum bacaan Al-Qur'an. Beberapa guru berhasil dibina tentang kompetensi mengaji melalui metode UMMI namun juga tak jarang dalam proses rekrutmen guru banyak guru yang lemah dalam kompetensi mengaji sehingga SDIT Baiz belum berhasil mendapatkan guru yang sesuai dengan standar kompetensi yang ditentukan oleh sekolah. Masalah yang sering ditemui saat proses rekrutmen, calon guru mampu membaca Al-Qur'an namun tidak sesuai dengan tajwid dan kurang menguasai tentang hukum bacaan Al-Qur'an sebagai syarat untuk mengajar di SDIT Baiz yang menerapkan pola pembelajaran dan mengaji dalam program Halaqah.

Permasalahan tersebut perlu segera dicari solusinya salah satunya adalah menggunakan teknik analisis masalah matrik USG untuk mengetahui seberapa penting kompetensi mengaji dalam proses rekrutmen guru baru di SDIT Baiz. Jangan sampai SDIT Baiz selalu mengahadapi masalah yang sama setiap akan melakukan rekrutmen guru baru dan akhirnya SDIT Baiz kesulitan mendapatkan guru baru karena syarat yang diajukan dirasa berat bagi guru yang melamar di SDIT Baiz. Oleh karena itu, analisis masalah diperlukan untuk menemukan solusi yang dirasa tepat untuk menyelesakan masalah guru yang melamar di SDIT Baiz kurang memiliki kompetensi mengaji.

\section{METODE}

Metode yang digunakan dalam penelitian ini adalah kualitatif untuk memperoleh informasi secara langsung dari pihak-pihak terkait dan mencari informasi mendalam tentang suatu masalah. Data diperoleh melalui studi lapangan yang diperoleh dari kegiatan wawancara dengan kepala sekolah dan guru SDIT Baiz, pengamatan langsung ke sekolah. Penelitian dilakukan dengan melakukan wawancara yang mendalam dengan kepala sekolah SDIT Baiz tentang masalah-masalah sumber daya manusia yang menjadi kendala di SDIT Baiz hingga kemudian ditemukan masalah tentang kompetensi mengaji guru dan calon guru yang melamar di SDIT Baiz yang dirasa belum memnuhi standar kompetensi yang diinginkan oleh SDIT Baiz.

Kemudian penelitian dilanjutkan dengan melakukan pengamatan ketika saat program Halaqah berlangsung untuk melihat seperti apa kegiatan pembelajaran yang dilakukan di SDIT Baiz yang memadukan pembelajaran umum dengan mengaji kitab suci Al-Qur'an yang sesuai dengan tajwid dan metode UMMI yang sesuai dengan program yang diterapkan di SDIT Baiz. Penelitian dilanjutkan dengan melihat dokumen-dokumen yang berkaitan dengan proses rekrutmen guru baru di SDIT Baiz.

Dari penelitian tersebut diperoleh informasi tentang masalah yang sering dihadapi oleh SDIT Baiz saat melakukan 
proses rekrutmen guru baru. Namun untuk menganalisis keabsahan data, maka peneliti menggunakan triangulasi sumber, yang didapatkan dari kepala sekolah dan beberapa guru. Selanjutnya melakukan studi literatur untuk memperdalam wawasan tentang teori teknik analisis masalah matrik USG. Sedangkan pendapat lain menurut Sugiono (2005) bahwa studi literatur merupakan studi yang menggali informasi atau data melalui catatan peristiwa yang sudah terekam pada suatu karya ilmiah yang berbentuk tulisan, gambar, atau karya-karya monumental dari seseorang. Literatur yang dicari dan dipelajari adalah literatur-literatur tentang teknik analisis masalah terutama tentang teknik analisis masalah matrik USG baik dari buku, artikel, jurnal, dan sumber internet.

\section{TEMUAN PENELITIAN DAN PEMBAHASAN}

\section{Temuan Penelitian}

Berdasarkan hasil penelitian yang dilakukan dengan pendekatan penelitian kualitatif, melakukan wawancara yang mendalam dengan kepala sekolah SDIT Baiz selaku informan kunci, studi pengamatan, dan studi dokumentasi. Hasil dari penelitian tersebut adalah guru atau calon guru yang melamar di SDIT Baiz kurang memiliki kompetensi mengaji sesuai yang diharapkan oleh SDIT Baiz karena kurang memahami tentang tajwid dan hukum bacaan Al-Qur'an. Masalah ini menjadi salah satu masalah yang jamak ditemui saat rekrutmen guru baru di SDIT Baiz sehingga terkadang dalam proses rekrutmen, sekolah gagal merekrut guru baru karena tidak ada calon guru baru yang lolos saat tes mengaji dan hafalan tajwid serta hukum bacaan AlQur'an. Informasi ini diperoleh berdasarkan wawancara peneliti dengan kepala sekolah sedangkan pola pembelajaran di SDIT Baiz berdasarkan hasil pengamatan memang menggunakan perpaduan antara pembelajaran formal umum seperti biasa dengan pembelajaran mengaji menggunakan metode UMMI yang dikemas dalam program Halaqah.

\section{Pembahasan}

\section{Masalah SDIT Baiz}

Standar tidak terpenuhi saat proses seleksi seringkali menjadi masalah saat proses seleksi guru atau tenaga kependidikan baru di SDIT Baiz. Dari penuturan kepala sekolah diperoleh informasi bahwa calon guru atau tenaga kependidikan baru yang melamar lemah dalam aspek mengaji kitab suci Al-Qur'an. SDIT Baiz, sebagai sekolah dengan ciri khas Agama Islam dan adanya program bimbingan mengaji yang ditawarkan oleh sekolah, tentu guru diminta wajib memenuhi kompetensi mengaji karena akan berkaitan dengan minat masyarakat terhadap sekolah terutama di program bimbingan mengaji. Apabila bimbingan tersebut diabaikan karena alasan tidak adanya guru yang berkompeten, jelas akan mempengaruhi tingkat kepercayaan masyarakat terhadap sekolah sehingga diperlukan analisis yang mendalam dan solusi untuk mengatasi permasalahan tersebut (Halim Yustiyawan, Supriyanto, \& Mustiningsih, 2016; Hambali, 2016; Slameto, 2014).

Kompetensi mengaji yang sesuai dengan tajwid dan hukum bacaan Al-Qur'an menjadi masalah saat proses rekrutmen guru baru di SDIT Baiz memasuki fase tes mengaji. Sebagai sekolah berbasis Agama Islam, kompetensi mengaji menjadi syarat mutlak selain kompetensi wajib yang harus dimiliki oleh guru di SDIT Baiz selain kompetensi pedagogis, sosial, kepribadian, dan profesional. Masalah ini menjadi masalah yang sering ditemui saat proses rekrutmen guru baru dimana SDIT Baiz terkadang tidak memperoleh guru baru dari hasil rekrutmen tersebut karena semua guru yang melamar kurang menguasai kompetensi tersebut dan jika kondisi kebutuhan tenaga guru baru mendesak, SDIT Baiz merekrut guru yang kompetensi mengajinya kurang kemudian saat proses adaptasi dengan lingkungan sekolah, guru baru dibina melalui program mengaji setelah jam mengajar guru yang bersangkutan selesai atau berakhir. 


\section{Teknik Analisis Masalah Matrik USG}

Guna melihat standar apa yang penting dibutuhkan dalam seleksi guru di SDIT Baiz dari uraian analisis penyebab masalah diatas. Tentu harus diidentifikasi masalah standar apa saja yang sesuai dengan kebutuhan rekrutmen dan seleksi yang dilakukan oleh SDIT Baiz. Jika melihat dari pola seleksi yang terdiri dari tes tulis, tes potensi akademik, tes mengaji, dan tes psikologi dimana tes mengaji menjadi masalah saat seleksi karena pelamar kesulitan di tes mengaji.

Analisis masalah menggunakan teknik matriks USG dirasa cocok untuk menganalisis masalah tersebut, hal ini terkait apakah tes mengaji penar-benar menjadi masalah yang serius bagi pelamar karena seringkali mereka tidak memenuhi standar sekolah di tes tersebut. Menurut Kepner dan Tragoe (1981) analisis matriks USG diperlukan untuk melihat mendesaknya waktu untuk menyelesaikan masalah, dampak yang ditimbulkan bagi sekolah, masalah yang akan muncul di kemudian hari saat standar tersebut tidak terpenuhi. Lembaga Administrasi Negara (2008) mengemukakan ada beberapa langkahlangkah yang dapat dilakukan saat melakukan analisis masalah dengan menggunakan pendekatan matrik USG yakni: (1) persiapan gugus tugas dengan susunan petugas untuk metode teknik scoring meliputi pimpinan USG, petugas pencatat flipchart, petugas scoring, personil yang bertugas sebagai notulis, dan persiapan ruang pertemuan, (2) persiapan peralatan atau sarana meliputi daftar hadir, papan tulis, alat tulis, kalkulator, dan peserta, (3) data yang dibutuhkan, dan (4) proses dinamika kelompok. Santoso (2017) metode matrik USG sangat cocok untuk menemukan skala prioritas dalam menyelesaikan suatu masalah yang ada pada suatu lembaga, organisasi, atau perusahaan. Oleh karena itu masalah tersebut akan dianalisis dengan pendekatan matriks USG pada Tabel 1 Matriks USG standar tidak terpenuhi saat proses seleksi.
(1) Pelamar tidak bisa mengaji sama sekali

(2) Pelamar bisa mengaji namun tajwid nya kurang bagus

(3) Pelamar bisa mengaji namun tidak hafal hukum-hukum bacaan kitab suci AlQur'an

(4) Pelamar bisa mengaji dan sangat menguasai hukum bacaan namun kompetensi mengajar kurang

Dari keempat uraian masalah yang dihadapi saat seleksi, dapat digunakan pendekatan urgensi, dampak yang paling tinggi pada sekolah, dan tingkat pertumbuhan masalah dengan memberikan angka untuk mengukur secara kuantitatif tingkat masalah dengan pendekatan USG. Dimana angka 2,3,4, dan 5 untuk mengukur rendah hingga tinggi nya urgensi masalah yang dihadapi saat seleksi guru baru yang tidak memenuhi standar mengaji di SDIT Baiz.

Tabel 1. Matriks USG

\begin{tabular}{|c|c|c|c|c|c|}
\hline \multirow[t]{2}{*}{ NO } & \multirow[t]{2}{*}{ MASALAH } & \multicolumn{3}{|c|}{ NILAI KRITERIA } & \multirow[t]{2}{*}{ TOTAL } \\
\hline & & $\mathbf{U}$ & $\mathbf{S}$ & $\mathbf{G}$ & \\
\hline 1 & $\begin{array}{l}\text { Pelamar tidak } \\
\text { bisa mengaji } \\
\text { sama sekali }\end{array}$ & 5 & 3 & 3 & 11 \\
\hline 2 & $\begin{array}{l}\text { Pelamar } \\
\text { bisa mengaji } \\
\text { namun } \\
\text { tajwidnya } \\
\text { kurang } \\
\text { bagus }\end{array}$ & 4 & 4 & 4 & 12 \\
\hline 3 & $\begin{array}{l}\text { Pelamar } \\
\text { bisa mengaji } \\
\text { namun tidak } \\
\text { hafal hukum- } \\
\text { hukum } \\
\text { bacaan kitab } \\
\text { suci Al- } \\
\text { Qur'an }\end{array}$ & 3 & 5 & 2 & 12 \\
\hline$\overline{4}$ & $\begin{array}{l}\text { Pelamar } \\
\text { bisa mengaji } \\
\text { dan sangat } \\
\text { menguasai } \\
\text { hukum } \\
\text { bacaan } \\
\text { namun } \\
\text { kompetensi }\end{array}$ & 4 & 5 & 4 & 13 \\
\hline
\end{tabular}


mengajar

kurang
Baiz, (2) kompetensi mengaji yang sesuai dengan tajwid dan hukum bacaan Al-Qur'an menjadi syarat mutlak yang harus dimiliki oleh guru baru yang mengikuti porses rekrutmen di SDIT Baiz karena model pembelajaran memadukan antara pembelajaran formal umum dengan pembelajaran mengaji menggunakan metode UMMI yang dikemas dalam program Halaqah, (3) teknik analisis masalah matrik USG dirasa tepat untuk menyelesaikan masalah sumber daya manusia yang ada di SDIT Baiz yakni masalah guru baru yang mengikuti proses rekrutmen kurang dalam kompetensi mengaji dan melalui teknik analisis masalah matrik USG dalam ditemukan prioritas pemecahan masalah tentang rekrutmen guru baru di SDIT Baiz.

\section{DAFTAR RUJUKAN}

Halim Yustiyawan, R., Supriyanto, A., \& Mustiningsih. (2016). Hubungan Pengembangan Karir, Kompetensi Profesional, Dan Motivasi Kerja Dengan Kinerja Guru Paud Di Kecamatan Driyorejo Kabupaten Gresik. Jurnal Pendidikan: Teori, Peneltian Dan Pengembangan.

Hambali, M. (2016). Manajemen Pengembangan Kompetensi Guru PAI. J-MPI (Jurnal Manajemen Pendidikan Islam). https://doi.org/10.18860/jmpi.v1i1.3229

Kepner, C.H \& Tregoe, B. 1981. Manajer Yang Rasional Edisi Terjemahan. Jakarta: Penerbit Erlangga

Lembaga Administrasi Negara. 2008. Modul Pendidikan dan Pelatihan Kepemimpinan Tingkat III. Jakarta: Lembaga Administrasi Negara Republik Indonesia.

Santoso, A.C. 2017. Strategi Pemasaran Dengan Mengurangi Komplain Pada UKM SKD. Prosiding Seminar Nasional Multi Disiplin IImu dan Call Of Paper Unisbank ke 32017 ISBN 9-789-7936499-93. 
Slameto, S. (2014). PermasalahanPermasalahan Terkait Dengan Profesi Guru Sd. Scholaria : Jurnal Pendidikan Dan Kebudayaan. https://doi.org/10.24246/j.scholaria.2014. v4.i3.p1-12

Sugiono. 2005. Memahami Penelitian Kualitatif. Bandung: Alfabeta.
Ulfatin,N. 2014. Metode Penelitian Kualitatif Dibidang Pendidikan: Teori dan Aplikasinya. Malang: Bayumedia Publishing.

Undang-Undang Nomor 14 Tahun 2005 Tentang Guru dan Dosen. 